\title{
RACJONALNOŚĆ SPRAWCÓW PRZESTĘPSTW PRZECIW MIENIU \\ - IMPLIKACJE DLA PROFILAKTYKI I RESOCJALIZACJI
}

\author{
DOMINIKa WóJcik \\ domino87@poczta.fm
}

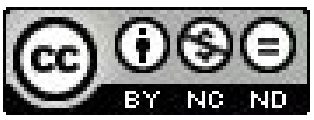

\section{WPROWADZENIE}

Społeczeństwo polskie w obliczu „kryzysu resocjalizacji” głośno wyraża potrzeby podnoszenia surowości karania przestępców. Wyniki sondaży i badań opinii publicznej pokazuja, że Polacy domagają się zaostrzenia kar - odwołując się do ich funkcji odstraszającej przed podjęciem decyzji o wkroczeniu na drogę przestępczą oraz przed powrotem na nią. Na ile jednak zagrożenie potencjalnym ukaraniem stanowi barierę przed popełnianiem przestępstw? Czy w momencie planowania i realizacji czynu, przestępcy mają świadomość grożącej za nie kary? Czy zachowanie przestępcze jest racjonalnym, świadomym wyborem przestępcy podjętym na podstawie prostego bilansu zysków i strat?

Statystyki Służby Więziennej wyraźnie wskazują na przestępstwa przeciwko mieniu, jako na najczęściej popełniane i tym samym stanowiące największy problem społeczny. W roku 1990 przestępstwa przeciw mieniu stanowily 84,7\% ogółu przestępstw; w 2007 r. nieco mniej, bo 53,9\% ogółu ${ }^{1}$. Ich liczba w porównaniu do lat 2007 i 2010 spadła nieznacznie. Według statystyk, znacząco spada natomiast liczba przestępstw przeciw zdrowiu i życiu². Czy oznacza to, że oddziaływanie na osoby dokonujące „drobnych" przestępstw jest stosunkowo najmniej skuteczne? Czy oddziaływania profilaktyczne skierowane do młodzieży nie przynoszą zamierzonego celu?

\section{RACJONALNOŚĆ W KRYMINOLOGICZNYCH TEORIACH WYJAŚNIAJĄCYCH ZJAWISKO PRZESTĘPCZOŚCI}

Klasyczna teoria decyzji przedstawia zachowanie racjonalnego decydenta, który dysponując pełną wiedzą o możliwościach, o ich użyteczności i prawdopodobieństwie zaistnienia określonych skutków swojej decyzji, dokonuje trafnego (najlepszego) wyboru. Wybiera on wariant przynoszący mu największe korzyści, kierując się zasadą użyteczności. Opisywany decydent kieruje się również zasadą prawdopodobieństwa - bierze bowiem pod uwagę szanse zaistnienia określonych skutków dokonanego wyboru. Pomimo wielu modyfikacji klasyczna teoria decyzji nadal nie jest $\mathrm{w}$ pełni trafna w wyjaśnianiu, $\mathrm{w}$ jaki sposób ludzie rzeczywiście podejmują decyzje. $\mathrm{W}$ codziennym życiu, decydent zazwyczaj nie ma pełnego dostępu do rzetelnych informacji - jego wiedza na dany temat jest ograniczona. Dodatkowo, podjęcie racjonalnej decyzji przez rozważanie możliwych opcji, ryzyka, prawdopodobieństwa konsekwencji, użyteczności itd. wymaga czasu - w rzeczywistości zaś podjęcie często trudnej decyzji wymagane jest natychmiastowo ${ }^{3}$.

Jak pisze Jan Strelau, obecnie jedną z najbardziej liczących się koncepcji wyjaśniających zachowanie ludzi stojących $\mathrm{w}$ obliczu podjęcia decyzji $\mathrm{w}$ warunkach ryzyka, jest teoria perspektywy. W Polsce koncepcję tę spopularyzował Tadeusz Tyszka. Jest ona ściśle powiązana z efektem obramowania opisanym przez Daniela Kahnemana - użycie określonych słów w celu przed-

\footnotetext{
A. Siemaszko, B. Gruszczyńska, M. Marczewski, Atlas przestępczości w Polsce 4, Warszawa 2009.

Dane statystyczne Stużby Więziennej ze strony internetowej http://sw.gov.pl.

Por. J. Kozielecki, Psychologiczna teoria decyzji, Warszawa 1977; M. Goszczyńska, Człowiek wobec zagrożén. Uwarunkowania oceny i akceptacji ryzyka, Warszawa 1997.
} 
stawienia problemu decyzyjnego lub też przedstawienie go w określonym kontekście wyzwala zupełnie różne reprezentacje poznawcze owego problemu, co w efekcie prowadzi do różnych decyzji, choć istota zagadnienia pozostaje niezmienna ${ }^{4}$.

Teorie podejmowania decyzji zostały zaczerpnięte na grunt kryminologii, wyjaśniając działania przestępcze jako funkcję oczekiwanej nagrody i kary, ważonych przez subiektywne prawdopodobieństwo wykrycia. W 1996 r. Steve Jakobs przeprowadził wywiady z czterdziestoma aktywnymi dilerami narkotykowymi. Wynikało z nich, że ich działania były determinowane wyłącznie maksymalizacją dochodów i minimalizowaniem ryzyka aresztowania ${ }^{5}$. Szeroko opisywana w literaturze teoria kontroli Travisa Hirschiego ${ }^{6}$ bliska jest ideom racjonalnego wyboru - wyjaśnia skłonność młodych do angażowania się w działalność przestępczą w kategoriach preferencji (przywiązanie, przekonanie), kosztów alternatywnych (zobowiązania) i dostępności zasobów (zaangażowanie) $)^{7}$.

Podejście nazywane w literaturze economies of crime popularność zyskało pod koniec lat 60tych, po publikacji artykułu Gary S. Beckera pt. Crime and punishment. Założenia tej teorii głosza, że przestępca niczym nie wyróżnia się spośród praworządnych obywateli, a jego działania są wynikiem racjonalnej decyzji dotyczącej zysków i strat wynikających z danego zachowania. Do popełnienia przestępstwa dochodzi (zgodnie z tą teoria), gdy oczekiwane zyski przewyższają koszty ich uzyskania. W owe koszta wpisywane są stracone możliwości, tzn. to, co jednostka mogłaby osiagnąć w wyniku konformistycznej działalności, w czasie, który przeznacza na popełnienie przestępstwa; oraz oczekiwana wartość kary - iloczyn kosztów, jakie przestępca przypisuje sankcjom przewidzianym za to przestępstwo i prawdopodobieństwo ujęcia i skazania. Oczekiwane zyski natomiast mogą być wszelako rozumiane - pieniądze i dobra materialne ( $\mathrm{np}$. w przypadku kradzieży, rozboju), satysfakcja, ulga (np. zemsta) czy też zyskanie szacunku lub rozgłosu.

Literatura kryminologiczna kwestię nierówności ekonomicznej porusza wielokrotnie. Zamysł przestępczy, zdaniem Willema Bongera9 ${ }^{9}$ jest wynikiem egoistycznego pobudzenia tendencji tkwiących w człowieku, poprzez system społeczny państwa burżuazyjnego ${ }^{10}$. Tendencje te rodzą się $\mathrm{w}$ społeczeństwie razem $\mathrm{z}$ rozwojem przemysłu, to jest wraz z podnoszeniem się poziomu życia. Horst Entorf i Hannes Spengler w Niemczech uznali, że ubóstwo i nierówności społeczne są typową zmienną wyjaśniającą zjawisko przestępczości. Istnieją etnograficzne dowody na to, że nastolatkowie w ubogich dzielnicach świadomie decydują się na podjęcie działań przestępczych, ponieważ mają bardzo ograniczone możliwości legalnego zdobywania porównywalnych dochodó $w^{11}$. Bez wątpienia warunki ekonomiczne stanowią jeden z głównych czynników popychających do popełniania przestępstw przeciw mieniu.

Jak piszą Anna Woźnica i Zbigniew Zaleski: ludzie pomimo uznawania norm prawnych, sa jednocześnie skłonni do ulegania pokusom łatwych korzyści. Powstrzymać ich może obawa przed ujawnieniem i sankcjami. „Prawo spełnia swoją rolę, gdy jego przekroczenie będzie wy-

4 J. Strelau, D. Doliński, Psychologia- podrẹcznik akademicki, t. 1, Gdańsk 2008, s. 483-487.

5 M. Hetchter, S. Kanazawa, Teoria racjonalnego wyboru a socjologia ttumu, [w] A. Jasińska-Kania, L. M. Nijakowski, J.

Szacki, M. Ziółkowski (wybór i oprac.), Wspótczesne teorie socjologiczne, Warszawa 2006, s. 172-173.

6 Por. A. Siemaszko, Granice tolerancji- o teoriach zachowan dewiacyjnych, Warszawa 2003; B. Hołyst, Kryminologia,

Warszawa 2009; J. Błachut, A. Gaberle, K. Krajewski, Kryminologia, Gdańsk 2004.

M. Hetchter, S. Kanazawa, dz. cyt., s. 172-173.

A. Kiersztyn, Czy bieda czyni złodzieja?, Warszawa 2008, s. 45 - 46.

Autor kryminologicznej teorii ekonomicznej, zawartej w Criminality and Economic Conditions, Boston 1916.

B. Hołyst, dz. cyt., s. 957.

1 Tamże, s. 173. 
woływało wystarczająco mocny dyskomfort emocjonalny (lęk, wstyd, wina), moralny (etyka), związany z samooceną (idealne Ja), z wrażliwością na krzywdę innych"12. Kara zatem winna być na tyle surowa i nieunikniona, by znacznie przewyższać potencjalne korzyści płynące z popełnienia przestępstwa. Teza ta zakłada jednak, że w chwili podejmowania decyzji o podjęciu działania przestępczego, decydent bierze pod uwagę możliwość ukarania.

Kolejnym, ważnym z punktu widzenia motywacji, jest związek popełnionego czynu z nadużywaniem środków psychoaktywnych. Mówiąc o powiązaniu nadużywania środków psychoaktywnych i przestępczości, rozumiem popełnienie przestępstwa w stanie odurzenia narkotycznego lub alkoholowego. K. Krajewski uważa, iż istnienie zależności pomiędzy używaniem narkotyków a przestępczością jest sprawą niemalże oczywista, nawet dla laików. W raportach ONZ stwierdzono, że istnieją przestęp cy celowo odurzający się, aby dodać sobie odwagi przed popełnieniem przestępstwa. Wbrew oczekiwaniom i wiedzy potocznej, przestępstwami popełnianymi pod wpływem narkotyków są głównie przestępstwa z użyciem przemocy, a nie jak zdawać by się mogło kradzieże, rabunki ${ }^{13}$. Choć K. Krajewski wymienia je, jako najczęstsze, mające na celu głównie zdobycie środków odurzających, badania amerykańskie, na które powołuje się B. Hołyst ${ }^{14}$ pokazują wyraźnie, że $\mathrm{w}$ grupie przestępstw pozostających $\mathrm{w}$ ścisłej zależności z używaniem środków psychoaktywnych, pozostają głównie przestępstwa z użyciem przemocy. Autor ponadto neguje związek narkomanii z przestępczością obalając dotychczasowe zdania innych badaczy zjawiska. Nie ma bowiem dostatecznych danych dotyczących powiązania narkotyków z przestępstwami przeciwko mieniu ${ }^{15}$. Prowadzone przeze mnie badania winny pokazać, czy istnieje zależność pomiędzy używaniem środków psychoaktywnych a popełnianiem przestępstw przeciw mieniu.

Podobnie przedstawiają się wyniki badań poszukujących związków alkoholu z przestępczością $^{16}$. Badania takie prowadzili m.in. Jean Constant i Jean Pinatel. Autorzy badali zależności między nadużywaniem alkoholu a przestępczością i tak: J. Constant wnioskował, że miejsce i czas popełniania przestępstw jest bezpośrednio powiązany z miejscem i czasem spożywania alkoholu. J. Pinatel natomiast, że alkohol ma związek z popełnianiem specyficznych rodzajów przestępstw, jak np. zabójstw, gwałtów, uszkodzeń ciała czy znęcania się nad dziećmi ${ }^{17}$. Choć Antoni Frydel, powołując się na wyniki swoich badań, pisze, że 95 \% sprawców rozbojów w chwili popełniania czynu pozostawało pod wpływem alkoholu ${ }^{18}$, B. Hołyst uważa, że na temat powiązań alkoholu z przestępstwami przeciw mieniu nie ma dowodów ${ }^{19}$. Wielu autorów zajmujących się zjawiskiem, zaznacza nawet, że w stosunku do przestępstw agresywnych, odsetek sprawców działających pod wpływem alkoholu i dokonującym kradzieży oraz innych przestępstw przeciw mieniu jest niski, wręcz nieistotny ${ }^{20}$. Myślę, że kwestia ta warta jest szczególnego zainteresowania badawczego.

12 A. Woźnicka, Z. Zaleski, Uleganie pokusie nielegalnego czynu z perspektywy psychologicznej, [w] M. Kuć, I. Niewiadomska (red.), Kara kryminalna analiza psychologiczno prawna, Lublin 2004, s. 121.

13 Tamże.

14 B. Hołyst, Narkomania a przestępczość, Warszawa 1993, s. 51-52.

15 Tamże.

16 Problematyka ta jest często poruszana w literaturze kryminologicznej, jednak głównie w ujęciu przestępczości z użyciem przemocy.

17 B. Hołyst, Kryminologia..., dz. cyt., s. 569-578.

18 Zob. H. Piotrowski i in., Rozboje na terenie Łodzi w 1965, „Służba MO” 1966, nr 4-5; A. Frydel, Przestępstwo rozboju w świetle kryminalistyki i kryminologii, Warszawa 1974, s. 64.

19 B. Hołyst, Narkomania..., dz. cyt.

20 A. Papierz, M. Stożek (red.), Kryminologia-repetytorium, Warszawa 2010. 


\section{ZAŁOŻenia BADAWCZE}

Badanie racjonalności sprawców przestępstw pozwoli na określenie, czy i jakie zmiany można wprowadzić do polskiej polityki karnej, aby obniżyć współczynnik przestępczości i podnieść efektywność oddziaływań resocjalizacyjnych. Badania sondażowe (za pomocą kwestionariusza ankiety) przeprowadzone zostały wśród skazanych prawomocnym wyrokiem sądu za przestępstwa przeciwko mieniu, przebywających w Zakładzie Karnym nr 1, oraz w Areszcie Śledczym nr 1 we Wrocławiu. Spośród 200 arkuszy kwestionariusza, jedynie 40 kwestionariuszy spełniało wszystkie wymagania badawcze. Pozostałe ankiety nie wróciły, lub wróciły niewypełnione, zniszczone, czy wypełnione jedynie częściowo.

Kwestionariusz ankiety zawierał w większości pytania zamknięte dopuszczające wybór odpowiedzi spośród dwóch wariantów (tak/nie) lub podanej kafeterii. Kilka pytań stanowiących dopełnienia poprzednich pozwalały na swobodne udzielenie odpowiedzi (pytania otwarte).

\section{INTERPRETACJA WYNIKÓW BADAŃ}

Najliczniejszą grupę ankietowanych stanowiły osoby młode, do 35 lat (51\% badanych). Młodociani i osoby po 40 roku życia (grupy skrajne) stanowiły niecałe $30 \%$ ankietowanych. Znaczna większość badanych to osoby z wykształceniem zawodowym (46\%); mechanik, budowlaniec, stolarz, ślusarz. Kolejna, co do liczebności grupą są osoby posiadające wykształcenie podstawowe (31\%). Tylko 5\% badanych nie ma żadnego wykształcenia, 15 \% ma wykształcenie średnie. Tylko jedna osoba zadeklarowała posiadanie wyższego wykształcenia. Wyniki te potwierdzają się częściowo z wnioskami A. Gaberle, który, przywołując wyniki własnych badań, wskazuje jednoznacznie na niskie wykształcenie przestępców - szczególnie sprawców przestępstw przeciw mieniu, których wykształcenie jest najczęściej niższe niż podstawowe ${ }^{21}$. Myślę, że konieczne jest tutaj uwzględnienie zmian społecznych, jakie zachodziły w Polsce na przestrzeni lat. Jak pisze Ewa Kramarz z Polskiego Towarzystwa Psychiatrii Sądowej kwestia wykształcenia sprawców przestępstw uległa znacznej zmianie - obecnie wykształcenie sprawców przestępstw jest wyższe niż 20 - 30 lat temu. Teraz przestępcami są osoby nawet z wyższym wykształceniem²2.

Spośród badanych ponad połowa (54\%) to osoby uzależnione (od alkoholu i/ lub narkotyków), z czego 35\% to alkoholicy. 11\% zadeklarowało stwierdzone uzależnienie od narkotyków, a 8\% - oba (od alkoholu i narkotyków). Przemysław Piotrkowski, powołując się na dane statystyczne ze strony internetowej Komendy Głównej Policji, pisze, że 2/3 dorosłych i 1/3 nieletnich podejrzewanych o popełnienie przestępstw o charakterze rozbójniczym była pod wpływem alkoholu ${ }^{23}$. Problem nadużywania substancji psychoaktywnych i ich związku z przestępczością powinien zostać bardziej nagłośniony. Być może, gdyby spadała liczba osób nadużywających alkoholu i/ lub narkotyków poziom przestępczości również osiągnąłby tendencję spadkową?

Aż 90\% ankietowanych było uprzednio karanych za popełnienie przestępstwa. W 89\% były to przestępstwa przeciw mieniu ${ }^{24}$. Dwie osoby karane były za przestępstwa przeciw życiu i zdrowiu, jedna za prowadzenie pojazdu pod wpływem alkoholu. Przeważająca część (84\%) odbywała już wcześniej karę pozbawienia wolności w zakładzie karnym. W większości respondenci byli karani już w okresie adolescencji. Najczęściej było to umieszczenie pod nadzorem kuratora

21 A. Gaberle, Patologia społeczna, Warszawa 1993, s. 246.

22 E. Ornacka, Portret wspótczesnego przestępcy, „Wprost” 2010, nr 21 (1424).

23 P. Piotrkowski, Rozbój - uwarunkowania psychospołeczne, motywacja i racjonalność sprawców, Warszawa 2011, s. 145147. Zaznaczyć należy, że autor powołuje się na dane dotyczące osób, którym jeszcze nie udowodniono winy.

24 Ankietowani w większości odbywali wcześniejsze wyroki za rozboje, wyłudzenia i kradzieże z włamaniem. 
sądowego (52,85\%), w ośrodku wychowawczym $(15,38 \%)$ i w zakładzie poprawczym $(10,26 \%)$. Pomimo doświadczenia wszelkich dolegliwości związanych z pobytem w zakładzie karnym, nie stanowity one wystarczającego hamulca przed powrotem na drogę przestępczą. Oznacza to, że zasądzona uprzednio kara nie odniosła pożądanego rezultatu - nie spełniła oczekiwanej funkcji prewencyjnej.

Ponad połowa (56\%) popełniła przestępstwo z udziałem wspólnika lub działając w grupie. Tylko jedna osoba jednoznacznie zadeklarowała popełnienie kradzieży samodzielnie. Pozostali nie udzielili odpowiedzi, lub udzielili odpowiedzi wykluczających się.

Tabela 1. Działanie pod presją

\begin{tabular}{|c|c|c|c|}
\hline PYTANIE & TakN $\%$ & $\begin{array}{c}\text { Nie } \\
\mathrm{N} \%\end{array}$ & SumaN \\
\hline Czy ktoś namówił Cię do popełnienia przestępstwa? & $1332,5 \%$ & $2767,5 \%$ & 40 \\
\hline Czy ktoś zmusił Cię do popełnienia przestępstwa? & $410 \%$ & $3690 \%$ & 40 \\
\hline
\end{tabular}

Źródło: opracowanie własne.

Znaczna większość ankietowanych zaprzeczała, aby w momencie popełnienia przestępstwa działała pod przymusem (90\%). Jedynie 4 osoby napisały, iż były do przestępstwa zmuszone; z czego trzech działałało pod presją kolegów; jeden spośród ankietowanych dopisat, że do przestępstwa „zmusiło go życie”. Większość spośród badanych jednak zadeklarowała, iż samodzielnie podjęła decyzję o popełnieniu przestępstwa. Osobami namawiającymi najczęściej byli koledzy (76,9\%). Jeden z ankietowanych wskazał na żonę, dwóch na sąsiada. Osadzeni twierdząc, że zostali zmuszeni przez kolegę, żonę czy też, jak niektórzy przez „życie”, w ten sposób kwestionują swoją odpowiedzialność za popełniony czyn. Ponad $60 \%$ sprawców zadeklarowała działanie pod wpływem substancji psychoaktywnych (alkoholu i/lub narkotyków) - co także można rozpatrywać jako próbę umniejszania własnej odpowiedzialności.

Celem podjętych badań było uzyskanie danych mogących stanowić potwierdzenie lub zaprzeczenie teorii podejmowania decyzji, racjonalnego wyboru. Badania były próbą odpowiedzi na pytanie: Czy popełnienie przestępstwa w rozumieniu prawa jest świadomą decyzją przestępcy, podjętą na podstawie prostego bilansu zysków i strat?, Czy osoba popełniająca czyn zabroniony w momencie planowania i realizacji przestępstwa, ma świadomość ciążącej za popełnienie tegoż czynu kary? oraz Czy zdaje sobie sprawę z tego, że może wyrządzać tym komuś krzywdę?

I tak: niewiele ponad połowa $(52,5 \%)$ ankietowanych zadeklarowała planowanie przestępstwa. Z czego w większości (42,85\%) planowanie to trwało mniej niż jeden tydzień, w $28,57 \%$ przypadków mniej niż jeden dzień. Dwie osoby planowały popełnienie czynu do miesiąca, jedna ponad rok. Trzy osoby nie udzieliły odpowiedzi.

Tabela 2. Analizowanie zysków i strat

\begin{tabular}{|c|c|c|c|}
\hline Planowanie czynu & TakN \% & $\begin{array}{c}\text { Nie } \\
\mathrm{N} \%\end{array}$ & SumaN \\
\hline Analizowanie potencjalnego zysku & $1263,16 \%$ & $736,84 \%$ & 19 \\
\hline Analizowanie potencjalnych strat & $736,84 \%$ & $947,37 \%$ & 16 \\
\hline
\end{tabular}

Źródło: opracowanie własne. 
Jak wynika z tabeli 2, osoby planujące popełnienie przestępstwa, znacznie częściej analizowały potencjalne zyski, w porównaniu z osobami nie planującymi czynu przestępczego. Rzadziej analizowały natomiast potencjalne straty i konsekwencje (różnica ok. 10\%). Osoby, które dokonały przestępstwa bez uprzedniego planowania, częściej zastanawiały się nad możliwymi konsekwencjami, rzadziej analizując (w stosunku do planujących) potencjalne straty.

Ankietowani zostali zapytani o to, czy w momencie popełnienia czynu lub już w trakcie jego planowania wiedzieli, że jest to czyn zakazany, zagrożony określoną karą? Oraz czy mimo tej wiedzy, świadomie zdecydowali się zaryzykować? I tak: większość (62\%) osadzonych zadeklarowała, że popełniając przestępstwo miała świadomość łamania prawa i ciążącej odpowiedzialności karnej.

Świadomość wyrządzania krzywdy i czynienia zła przedstawia się następująco:

\section{Wykres 1. Świadomość krzywdy}

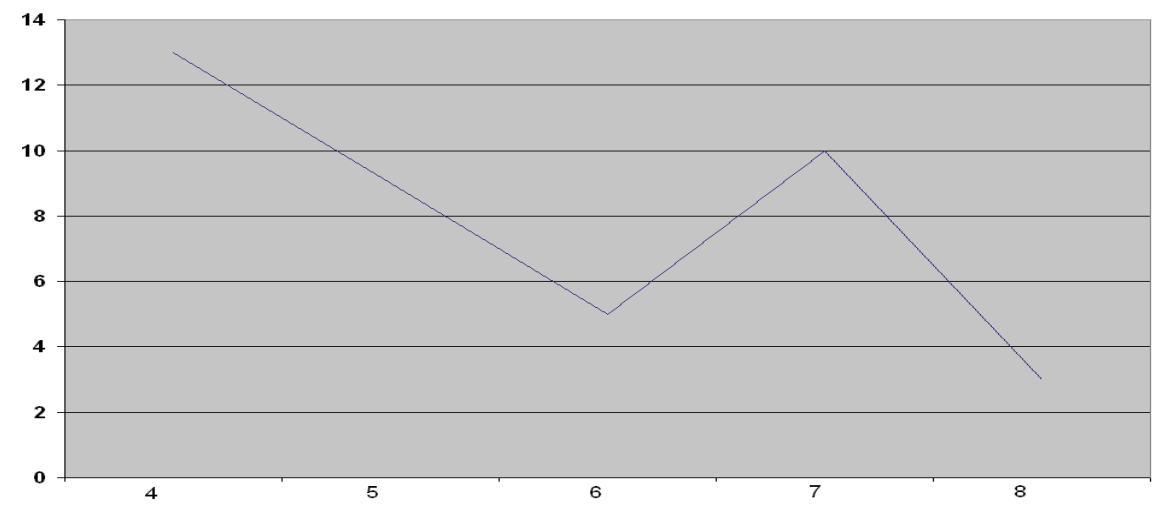

Źródło: opracowanie własne. Maksymalnym wynikiem, oznaczającym pełną świadomość wyrządzanej krzywdy, jest 4; minimalnym: 8 (ośx), oś y wyznacza ilość udzielonych odpowiedzi.

Rozkład tej zmiennej jest dość interesujący. Większość spośród respondentów (55\%), deklaruje pełną lub bardzo dużą świadomość wyrządzonej krzywdy (już w trakcie dokonywania przestępstwa). Spora część (25\%), nie miała świadomości wyrządzania zła (lub nie dopuszczała do siebie tych myśli). W większości przypadków respondenci zapytani o to, kogo skrzywdzili wskazywali na swoje rodziny i poszkodowanych. Zastanawiająca była także często pojawiająca się odpowiedź: „,samego siebie”. Daje to nadzieję na to, że sprawcy ci zrozumieli, że ich postępowanie jest nieopłacalne i krzywdzące dla nich samych. Może też wskazywać na egocentryzm ankietowanych, gdyż pomimo przekonania o wyrządzaniu komuś krzywdy zdecydowali się na popełnienie przestępstwa - prawdopodobnie licząc na osiagnięcie osobistych korzyści.

Kolejne pytania dotyczyły wiary osadzonego w to, że uda mu się unikną́ konsekwencji. Uzyskane dane przestawia tabela:

\section{Tabela 3. Uniknięcie odpowiedzialności}

\begin{tabular}{|c|c|c|c|}
\hline $\begin{array}{c}\text { Liczyl, że nie zostanie ujęty przez policję. } \\
\text { Liczyl, na uniewinnienie. }\end{array}$ & Tak & Nie & Suma \\
\hline Tak & $723,4 \%$ & N $\%$ & N \\
\hline Nie & $2376,7 \%$ & $770 \%$ & 10 \\
\hline
\end{tabular}

Źródło: opracowanie własne. 
Osadzeni w znacznej większości (76,7\%) liczyli na to, że nie zostaną ujęci przez organy ścigania. Tylko $10 \% \mathrm{z}$ ankietowanych deklaruje, że nie miała żadnych nadziei na ucieczkę przed wymiarem sprawiedliwości. Sześć osób, spośród badanych, miało nadzieję na uniknięcie kary (zarówno przez uniknięcie zatrzymania przez policję i uniewinnienie w sądzie). Trzy osoby, wiedziały, że nie uda im się zbiec przed policja, jednak mimo to, liczyły na uniewinnienie podczas procesu. Jednak w większości (70\%) ankietowani nie liczyli na uniewinnienie przed sądem.

\section{WNIOSKI}

Przeprowadzone badania wykazały wysoką powrotność do przestępstwa. W $90 \%$ ankietowani byli wcześniej karani (w ponad połowie przypadków również, jako nieletni). Józef Wąsik, w badaniach prowadzonych w latach 1957-1961, wykazał, iż na drogę przestępczą powraca ok. 25\% karanych, w tym znaczna większość przestępców przeciw mieniu (ok. 60\%). Pomimo doświadczenia wszelkich dolegliwości związanych z pobytem w zakładzie karnym i oddziaływań wychowawczych w okresie adolescencji (umieszczenie w placówce wychowawczej, poprawczej czy terapeutycznej, pod nadzorem kuratora), nie stanowily one wystarczającego hamulca przed powrotem na drogę przestępczą. Oznacza to, że zasądzona uprzednio kara nie odniosła pożądanego rezultatu - nie spełniła oczekiwanej funkcji prewencyjnej i resocjalizacyjnej. Brak środków finansowych i jasno sprecyzowanego programu oddziaływań oraz rosnąca biurokratyzacja placówek resocjalizacyjnych wyraźnie negatywnie wpływa na efektywność prowadzonych oddziaływań wychowawczych i terapeutycznych, które to powinny być głównym celem istnienia tych instytucji.

Wyniki przeprowadzonych badań wykazuja, że w większości przypadków sprawcy przestępstw przeciw mieniu zdają sobie sprawę z tego, że ich postępowanie łamie normy prawne i społeczne, że swoim zachowaniem mogą wyrządzići wyrządzają krzywdę. Uzyskane dane dotyczące bilansu zysku i strat są niejednoznaczne. Niewiele ponad połowa ankietowanych planowała popełnienie przestępstwa, z czego tylko część analizowała płynące z niego konsekwencje. Ze względu na trudności w ocenianiu wagi poszczególnych zmiennych (zysk, strata) niemożliwe było obliczenie wiarygodnego bilansu - w 90\% ankietowani za główną stratę wynikającą z przestępstwa podawali utratę wolności. Zysk prawie zawsze rozpatrywany był w kategoriach materialnych ${ }^{25}$. Trudno zatem ocenić, która zmienna przeważała, gdyż niemożliwością jest porównywanie wartości pieniądza do wolności. Osoby deklarujące planowanie czynu przestępczego wyraźnie częściej szacowały możliwe zyski, minimalizując potencjalne straty oraz prawdopodobieństwo wykrycia i ukarania przez organy ścigania. Być może skłonność do kradzieży ujawniła się u respondentów z powodu nierówności ekonomicznych - badani często pochodzili z rodzin rozbitych, mieli niskie wykształcenie, nie pracowali, z czego można by wnioskować o ich trudnej sytuacji materialnej - jednak problem ten wymaga głębszego badania ${ }^{26}$.

Wyniki badań pokazały, że nie wysokość zasądzanej kary, ani też warunki jej wykonywania, a jedynie jej nieuchronność pełni funkcję prewencyjną przed popełnianiem przestępstwa. Większość spośród ankietowanych planowała popełnienie czynu, jednak o ile rozpatrywali oni możliwe konsekwencje, zdawali sobie sprawę z łamania prawa i ewentualnych konsekwencji płynących z ich działania. Liczyli jednak na nieudolność organów ścigania i uniknięcie odpowiedzialności. Oznacza to, iż konieczne jest podniesienie sprawności policji i prokuratury tak, aby ujawnienie,

${ }^{25}$ Obiektem popełnionego czynu najczęściej były pieniądze (75\%) i sprzęt elektroniczny (53\%), a także: samochód $(25 \%)$ i biżuteria (25\%). Rzadziej artykuły spożywcze $(15 \%)$, czy alkohol/ narkotyki $(13 \%)$.

26 Por. A. Kiersztyń, dz. cyt. 
ujęcie i oskarżenie sprawcy było nieuchronne. Podniesienie autorytetu organów ścigania z pewnością przynajmniej po części wpłynęłoby na zmniejszenie się liczby przestępstw w Polsce. Uzyskane w toku badania dane potwierdzają słowa C. Beccarii: „pewność ukarania zrobi zawsze większe wrażenie, niż strach przed inną surowszą kara, z którym łączy się nadzieja na bezkarność'"27.

Przestępcy przeciw mieniu ujawniają braki w sferze postaw zawierających pozytywne emocje i uczucia społeczne, które mogłyby generować jakiekolwiek skrupuły moralne. Pozwala to na zaplanowanie i przeprowadzenie włamania czy kradzieży z zachowaniem tzw. zimnej krwi. W większości dokonywanie tego rodzaju przestępstw nie ma bowiem charakteru okazjonalnego czy sytuacyjnego, a jest raczej działaniem przemyślanym i umotywowanym. Świadczy o tym prowadzenie obserwacji obiektu kradzieży i skrupulatne wykonywanie zamierzonego planu ${ }^{28}$. Potrzeba zatem szeroko zakrojonych działań profilaktycznych dla młodzieży - kształtujących w młodych ludziach pozytywne postawy społeczne.

Uzyskane dane zwracają także uwagę na jeszcze jeden poważny problem polskiego społeczeństwa. Bardzo wielu, bo ponad 60\% sprawców zadeklarowała działanie pod wpływem substancji psychoaktywnych (alkoholu i/lub narkotyków), z czego prawie wszyscy ( $54 \%$ ankietowanych) to osoby ze stwierdzonym uzależnieniem od alkoholu i/lub narkotyków. Być może problem alkoholizmu wymaga bardziej zdecydowanych działań ze strony ustawodawcy? Stale rośnie dostępność alkoholu (zarówno ekonomiczna, jak i fizyczna). Walkę z demoralizacją młodzieży i szeroko rozumianą przestępczością winno się wesprzeć prewencją uzależnień.

\section{BibLIOGRAFIA}

Błachut J., Gaberle A., Krajewski K., Kryminologia, Gdańsk 2007.

Gaberle A., Patologia społeczna, Warszawa 1993.

Goszczyńska M., Człowiek wobec zagrożeń. Uwarunkowania oceny i akceptacji ryzyka, Warszawa 1997.

Hołyst B., Kryminologia, Warszawa 2009.

Hołyst B., Narkomania a przestępczość, Warszawa 1993.

Hetchter M., Kanazawa S., Teoria racjonalnego wyboru a socjologia tłumu [w:] Jasińska- Kania A. , Nijakowski L. M., Szacki J., Ziółkowski M. (wybór i oprac.), Wspótczesne teorie socjologiczne, Warszawa 2006.

Kiersztyn A., Czy bieda czyni złodzieja?, Warszawa 2008.

Kozielecki J., Psychologiczna teoria decyzji, Warszawa 1977.

Piotrkowski P., Rozbój-uwarunkowania psychospołeczne, motywacja i racjonalność sprawców, Warszawa 2010.

Siemaszko A., Gruszczyńska B., Marczewski M., Atlas przestępczości w Polsce 4, Warszawa 2009.

Siemaszko A., Granice tolerancji- o teoriach zachowań dewiacyjnych, Warszawa 2003.

Stanik J. M., Rodzaje przestępstw a różnice osobowościowe ich sprawców, [w:] Kossowska A. (red.), Archizuum kryminologii, t. 29-30, 2007-2008, Warszawa 2009.

Strelau J., Doliński D., Psychologia- podręcznik akademicki, t. 1, Gdańsk 2008.

Wąsik J., Kara krótkoterminozwego pozbawienia wolności w Polsce, Wrocław 1981.

Woźnicka A., Zaleski Z., Uleganie pokusie nielegalnego czynu z perspektywy psychologicznej, [w:] Kuć M., Niewiadomska I. (red.), Kara kryminalna analiza psychologiczno prawna, Lublin 2004.

\section{AKTy PRAWne}

Kodeks Karny z dn. 6 czerwca 1997 r. (Dz. U. nr 88 poz. 553).

Kodeks Karny Wykonawczy z dn. 6 czerwca 1997 r. (Dz. U. z dn. 5 sierpnia 1997 Nr 90, poz. 557).

\section{Netografia}

http://sw.gov.pl.

27 C. Beccaria, T. Kaczmarek, Ogólne dyrektywy wymiaru kary w teorii i praktyce sądowej, Wrocław 1980, s. 44.

28 J. M. Stanik, Rodzaje przestępstw a różnice osobowościowe ich sprawców, [w:] A. Kossowska (red.), Archiwum kryminologii, t. 29-30, 2007-2008, Warszawa 2009, s. 201. 


\section{STRESZCZENIE}

Społeczeństwo polskie w obliczu „kryzysu resocjalizacji” głośno wyraża potrzeby podnoszenia surowości kar. Wyniki sondaży i badań opinii publicznej ukazują jednoznacznie, że Polacy domagają się zaostrzenia kar - odwołując się do funkcji odstraszającej przed podjęciem decyzji o wkroczeniu na drogę przestępczą oraz przed powrotem na nią. Na ile jednak zagrożenie potencjalnym ukaraniem stanowi barierę przed popełnianiem przestępstw? Artykuł porusza ważną kwestię racjonalności sprawców najczęściej popełnianych przestępstw w Polsce - przestępstw przeciw mieniu. Przeprowadzone wśród osadzonych badania pozwalają wysunąć tezę, że przestępcy w momencie podejmowania decyzji, nie dysponują wystarczającą wiedzą dotyczącą prawdopodobieństwa wystąpienia możliwych skutków, lub minimalizują potencjalne zagrożenia na koszt potencjalnych zysków. Uzyskane wyniki pozwalają na zarysowanie programu oddziaływań prewencyjnych i resocjalizacyjnych, które mogłyby wpłynąć na zmniejszenie się populacji skazanych za przestępstwa przeciw mieniu.

Słowa kluczowe: racjonalność, decyzja, przestępca, kara, resocjalizacja.

\section{Rationality of Property Criminals: Implications for Prevention and ReHABILITATION}

\section{Summary}

In light of the "rehabilitation crisis," Polish society expresses the need to introduce more severe penalties. The results of surveys and public opinion pools clearly show that the Poles demand heavier sanctions. Does a potential threat of punishment provide an effective deterrent against committing crimes?

This paper discusses the problem of rational thinking of property criminals. The study conducted among prisoners allows us to argue that the perpetrator at the stage of decision making is not acutely aware of the possible consequences of committing a crime. The obtained results would enable us to launch a program facilitating prevention and rehabilitation, which could lead to a decrease in the rate of property crimes.

Key words: rationality, the decision, the offender, punishment, resocialization. 